\title{
Measuring the effect of fuel treatments on forest carbon using landscape risk analysis
}

\author{
A. A. Ager ${ }^{1}$, M. A. Finney ${ }^{2}$, A. McMahan ${ }^{3}$, and J. Cathcart ${ }^{4}$ \\ ${ }^{1}$ USDA Forest Service, Pacific Northwest Research Station, Western Wildland Environmental Threat Assessment Center, \\ 3160 NE 3rd Street, Prineville, OR, 97754, USA \\ ${ }^{2}$ USDA Forest Service, Rocky Mountain Research Station, Fire Sciences Laboratory, 5775 Hwy. 10 West, Missoula, MT, \\ 59808, USA \\ ${ }^{3}$ USDA Forest Service, Forest Health Technology Enterprise Team, 2150A Centre Avenue, Fort Collins, CO, 80526, USA \\ ${ }^{4}$ Oregon Department of Forestry, 2600 State Street, Salem, OR, 97310, USA
}

Received: 3 January 2010 - Revised: 7 August 2010 - Accepted: 19 August 2010 - Published: 7 December 2010

\begin{abstract}
Wildfire simulation modelling was used to examine whether fuel reduction treatments can potentially reduce future wildfire emissions and provide carbon benefits. In contrast to previous reports, the current study modelled landscape scale effects of fuel treatments on fire spread and intensity, and used a probabilistic framework to quantify wildfire effects on carbon pools to account for stochastic wildfire occurrence. The study area was a 68474 ha watershed located on the Fremont-Winema National Forest in southeastern Oregon, USA. Fuel reduction treatments were simulated on $10 \%$ of the watershed $(19 \%$ of federal forestland). We simulated 30000 wildfires with random ignition locations under both treated and untreated landscapes to estimate the change in burn probability by flame length class resulting from the treatments. Carbon loss functions were then calculated with the Forest Vegetation Simulator for each stand in the study area to quantify change in carbon as a function of flame length. We then calculated the expected change in carbon from a random ignition and wildfire as the sum of the product of the carbon loss and the burn probabilities by flame length class. The expected carbon difference between the nontreatment and treatment scenarios was then calculated to quantify the effect of fuel treatments. Overall, the results show that the carbon loss from implementing fuel reduction treatments exceeded the expected carbon benefit associated with lowered burn probabilities and reduced fire severity on the treated landscape. Thus, fuel management activities
\end{abstract}

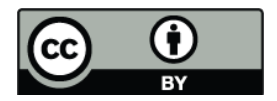

Correspondence to: A. A. Ager (aager@fs.fed.us) resulted in an expected net loss of carbon immediately after treatment. However, the findings represent a point in time estimate (wildfire immediately after treatments), and a temporal analysis with a probabilistic framework used here is needed to model carbon dynamics over the life cycle of the fuel treatments. Of particular importance is the longterm balance between emissions from the decay of dead trees killed by fire and carbon sequestration by forest regeneration following wildfire.

\section{Introduction}

There is a keen interest in the effect of wildfire risk mitigation programmes on the long-term carbon stocks on National Forests in the USA. These public forests cover 26.7 million ha and contain about $30 \%$ of the forest biomass in the USA. Their management, with respect to wildfire and other natural disturbances, can potentially have a significant impact on the US forest carbon balance. Fuel reduction projects are being scaled up on many of the fire-prone regions in response to financial and ecological losses from catastrophic wildfires (USDA-USDI, 2001; HFRA, 2003; Sexton, 2006). Fuel reduction activities will likely continue to grow over time in response to changing climate and the concomitant increase in fuel loads and fire (Bachelet et al., 2001; McKenzie et al., 2004; Gedalof et al., 2005). These activities use a combination of thinning, mechanical treatment of fuels and underburning to reduce surface and canopy fuels (Agee et al., 2000). From a carbon perspective, fuel reduction projects can reduce potential emissions by removing surface and canopy biomass, leaving a forest landscape that burns with a lower intensity (Finney and

Published by Copernicus Publications on behalf of the European Geosciences Union. 
Cohen, 2003; Hurteau et al., 2008; Reinhardt et al., 2008; North et al., 2009; Stephens et al., 2009; Reinhardt and Holsinger, 2010). Carbon emissions, associated with wildfire, are potentially mitigated by fuel treatments as a result of lower fire intensity. However, fuel management activities remove substantial carbon from the forest, much of which is not fixed in wood products, and also generate carbon emissions from prescribed fires and the decay of forest residue left on site. Thus, when a wildfire encounters a fuel treatment area, the potential carbon impact is strongly dependent on the ratio of the carbon removed by the fuel treatment to the reduction in carbon emissions from the fuel treatment. Both positive (Finkral and Evans, 2008; Hurteau et al., 2008; North et al., 2009; Stephens et al., 2009) and negative (Mitchell et al., 2009; Reinhardt and Holsinger, 2010) carbon outcomes have been reported in prior studies that examined stand level fuel treatments and fire behaviour. All of these studies employ a stand scale simulation of fuel treatments and wildfire, and make the implicit assumption that: 1) carbon effects from fuel treatments are confined within the spatial extent of the treated area; 2) wildfires encounter the treated stands, thus providing a basis for measuring the effect of the treatments on carbon. In terms of the first assumption, both empirical and simulation studies suggest fuel treatment effects on fire behaviour can extend well beyond the boundaries of the treated area (Finney et al., 2005, 2007; Ager et al., 2010). The assumption that treated stands are burned by wildfires implies that a burn probability is 1.0. Empirical estimates of burn probability from fire history data range from 0.001 to 0.1 in western US National Forests (Finney, 2005), and simulation studies suggest 100 fold differences in burn probability over short distances $(<5 \mathrm{~km})$ on some landscapes (Ager et al., 2007, 2010).

A more robust approach to examine the carbon effects from forest management activities requires a landscape analysis that accounts for the impact of fuel treatments on the likelihood and intensity of wildfires. Such an approach is possible by employing burn probability modelling (Finney et al., 2007; Parisien et al., 2010; Ager et al., 2007, 2010; Calkin et al., 2010) and the wildfire risk framework as proposed by Finney (2005)

$E[\mathrm{nvc}]=\sum_{i=1}^{N} \sum_{j=1}^{M} p\left(F_{i}\right)\left[B_{i j}-L_{i j}\right]$

where

$E[\mathrm{nvc}]=$ expected net value change,

$p\left(F_{i}\right)=$ probability of the $i$-th fire intensity, and

$B_{i j}$ and $L_{i j}$ are the respective benefits and losses afforded by the $j$-th value received from the $i$-th fire intensity,

$N=$ the number of fire intensity classes, and

$M=$ the number of values considered at risk to wildfire losses and benefits.

In the case of carbon, the losses and benefits are the changes

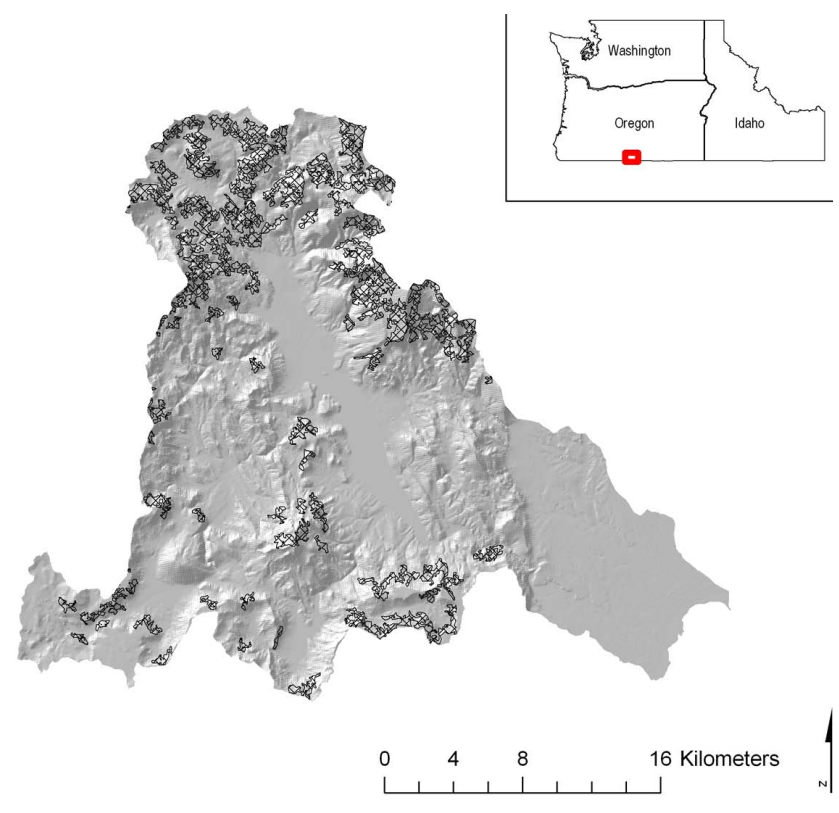

Fig. 1. Vicinity and relief map for the 68474 ha Drews Creek watershed, Fremont-Winema National Forest. Stands selected for fuel treatments are hatched areas.

in various carbon pools and emissions resulting from fuel treatments and wildfires. A further summation over time could be added to capture the temporal dynamics of emissions and sequestration associated with forest succession, future management and wildfires.

In this study, we investigated the carbon impacts of a typical fuel treatment program on a 68474 ha watershed within the Fremont-Winema National Forest located in Oregon, USA. We used a landscape risk approach to account for the effect of fuel treatments on burn probability and intensity within treated stands, and for the landscape as a whole. The change in wildfire behaviour was translated into expected carbon flux and compared to the treated and untreated landscapes. The results add to the existing knowledge on the effects of forest management on carbon, and advance the application of risk analysis to quantify wildfire.

\section{Methods}

\subsection{Study area}

The study area is the 68474 ha Drews Creek watershed located in Lake County, Oregon (Fig. 1). The watershed is considered to be at risk for severe wildfire, and several fuel treatment projects are ongoing and administered by the Fremont-Winema National Forest. The topography of the watershed consists mostly of gentle terrain, with elevations ranging from 1219 to $2133 \mathrm{~m}$ and the slope averaging about $15 \%$. Average annual precipitation within the watershed generally increases with the increasing elevation, and ranges 
from approximately $38 \mathrm{~cm}$ near Goose Lake at the southeastern edge of the watershed, to approximately $100 \mathrm{~cm}$ near Grizzly Peak at the northeast corner. A snowpack is generally in place from November through to June in the higher elevation areas of the watershed, reaching its maximum depth during the month of April.

\subsection{Vegetation and fuels}

Most of the Drews Creek watershed is forested (66\%), with grasslands and shrubs covering $22 \%$ of the area. Agricultural land and water covers the remaining $12 \%$ of the study area. The forests are dominated by pure and mixed stands of ponderosa pine (Pinus ponderosa), accounting for about $70 \%$ of the total forested area. The remaining forests consist of juniper (Juniperus occidentalis) woodlands (24\%), and white fir (Abies grandis) forests (6\%) and scattered stands of lodgepole pine (Pinus contorta). Agricultural lands are concentrated in the Goose Lake basin and are under irrigation much of the summer.

The watershed has been subjected to extensive forest management activities, including harvesting and prescribed burning. Most of the ponderosa pine-dominated stands below $1600 \mathrm{~m}$ in elevation have received at least one prescribed burn treatment in the past 50-80 years, the exceptions being the Quartz Creek sub-watershed and the Chandler Creek drainage, forming the northern tier of the watershed. In the managed ponderosa pine stands, typical fuel loadings range from 4 to 11 tonnes $\mathrm{ha}^{-1}$, and unmanaged stands contain fuel loads ranging from 7 to 34 tonnes ha $^{-1}$. In the higher elevation white fir stands, surface fuel loadings range from 34 to as high as 112 tonnes ha ${ }^{-1}$ or more.

Fire history data for the study area indicated 688 recorded ignitions during the period of 1949-1999, almost entirely by lightning. All fires were actively suppressed, with $88 \%$ contained to less than 0.1 ha ( 0.25 acres), and $10 \%$ contained between 0.1 and 4 ha (0.26-9.9 acres). Forty-four fires larger than 4 ha occurred over this period, and the total area burned for these fires is approximately $3640 \mathrm{ha}$.

\subsection{Vegetation and fuels data}

Forest vegetation data were derived from the Gradient Nearest Neighbour Mapping Project (GNN, http://www.fsl.orst. edu/lemma/main.php?project=method\&id=home $)(O h m a n n$ and Gregory, 2002). The GNN process assigned forest inventory plots to each $30 \mathrm{~m}$ pixel in the project area based on associations of satellite, topographic and other data. The plot data contained both dead and live trees and were used to model fuel treatments and derive canopy fuels for fire modelling as described below.

Surface fuel model data (Scott and Burgan, 2005) were obtained from the LANDFIRE project (www.landfire.gov). LANDFIRE data consist of nationwide $30 \mathrm{~m}$ pixel data that are widely used for wildfire modelling (Rollins, 2009). The
LANDFIRE data were also used to filter forested versus nonforested areas in the study area based on the fuel model. Grass, shrub, water, rock and agriculture fuel models (Scott and Burgan, 2005) were classified as non-forest.

Both the GNN and LANDFIRE data were obtained for the area adjacent to the watershed as defined by a $10 \mathrm{~km}$, buffered minimum bounding rectangle around the watershed boundary. In this way, simulated wildfires originating outside the boundary were included in the calculation of wildfire impacts on carbon.

\subsection{Modelling vegetation and fuel treatments}

We modelled forest vegetation and fuels using the Southern Oregon variant of the Forest Vegetation Simulator (FVS, Dixon, 2003), and the Fire and Fuels Extension to FVS (FVS-FFE, Reinhardt and Crookston, 2003). FVS is an individual-tree, distance-independent growth and yield model that is widely used to model fuel treatments and other stand management activities. FFE-FVS links FVS to fire behaviour (Scott and Burgan, 2005), and fire effects models (Reinhardt et al., 1997). Pre- and post-processing of FVS simulations and FVS-FFE outputs were performed with ArcFuels (Ager et al., 2006).

Stands were selected for fuel treatment based on the criteria developed by staff on the Fremont-Winema National Forest. Initially these criteria included a minimum basal area threshold, distance to road $(<300 \mathrm{~m})$ and slope $(<15 \%)$. Nearly all stands that met the basal area criteria also met the distance to road and slope criteria and, hence, the latter two criteria were dropped. The basal area threshold criteria used were $16 \mathrm{~m}^{2} \mathrm{ha}^{-1}\left(70 \mathrm{ft}^{2} \mathrm{a}^{-1}\right)$ for mixed conifer or firdominated stands and $11.5 \mathrm{~m}^{2} \mathrm{ha}^{-1}\left(50 \mathrm{ft}^{2} \mathrm{a}^{-1}\right)$ for pine dominated stands. Selected pixels were then aggregated into treatment units with a minimum size of 6 ha $(15$ acres $)$ by first kernel density smoothing the selected pixels, and then retaining only those pixels that exceeded an arbitrary density threshold that produced a feasible treatment map based on reviews by Forest staff. The resulting 94 treatment polygons covered 7180 ha and averaged 71 ha in area (Fig. 1). The treatment units covered approximately $10 \%$ of the Drews Creek watershed area and 19\% of the Fremont-Winema National Forest ownership within the watershed.

The fuel reduction treatments were simulated with FVS and consisted of a 3 year sequence of thinning from below, site removal of surface fuels and under burning, as used previously by the authors (Ager et al., 2007) and fine tuned based on operational guidelines from the Fremont-Winema National Forest. The simulated thinning reduced the basal area to the thresholds as described above. Under burning and the mechanical treatment of surface fuels was simulated with the FVS-FFE keywords SIMFIRE and FUELMOVE (Reinhardt and Crookston, 2003). Fuel treatment prescriptions for thinning from below had no upper diameter limit and specified retention of fire-tolerant ponderosa pine and 
Table 1. Fuel moisture values used in the wildfire simulations. Parameters obtained from fire management and silviculture specialists, Lakeview Ranger District, Fremont-Winema National Forest.

\begin{tabular}{lc}
\hline Fuel type & $\begin{array}{c}\text { Moisture } \\
(\%)\end{array}$ \\
\hline $1 \mathrm{~h}$ & 4 \\
$10 \mathrm{~h}$ & 5 \\
$100 \mathrm{~h}$ & 7 \\
Live herbaceous & 60 \\
Live woody & 62 \\
\hline
\end{tabular}

favoured the removal of white fir. Surface fuel treatments simulated the removal of $90 \%$ of the material from 0.4 to $30.5 \mathrm{~cm}$ (1-12 inches). Under burning was then simulated using weather conditions and fuel moisture guidelines provided by fuels specialists on the Fremont-Winema National Forest (Table 1). The treatment parameters are well supported by empirical studies (van Wagtendonk, 1996; Stephens and Moghaddas, 2005; Stephens et al., 2009; Vaillant et al., 2009).

Each treatment alternative was simulated with FVS and the post treatment outputs for canopy bulk density $\left(\mathrm{kg} \mathrm{m}^{-3}\right)$, height to live crown (ft), total stand height (ft), canopy cover (\%) and fuel model were then used to build $30 \times 30 \mathrm{~m}$ raster input files for the fire simulations described below. We overrode the FVS-FFE fuel model selection on treated stands and assumed a post-treatment fire spread rate and behaviour equal to fuel model TL1 (Scott and Burgan, 2005) based on local experience and input from fire managers.

\subsection{Wildfire simulations}

We simulated wildfire for the treated and untreated scenarios using the minimum travel time (MTT) fire spread algorithm of Finney (2002), as implemented in a command line version of FlamMap called "Randig" (Finney, 2006). The MTT algorithm replicates the fire growth by Huygens' principle where the growth and behaviour of the fire edge is a vector or wave front (Richards, 1990; Finney, 2002). This method results in less distortion of fire shape and response to temporally varying conditions than techniques that simulate fire growth from cell-to-cell on a gridded landscape (Finney, 2002). Extensive testing over the years has demonstrated that the Huygens' principle, originally incorporated into Farsite (Finney, 1998) and later approximated in the more efficient MTT algorithm, can accurately predict fire spread and replicate large fire boundaries on heterogeneous landscapes (Sanderlin and Van Gelder, 1977; Anderson et al., 1982; Knight and Coleman, 1993; Finney, 1994; Miller and Yool, 2002; LaCroix et al., 2006; Ager et al., 2007, 2010; Arca et al., 2007; Krasnow et al., 2009; Carmel et al., 2009; Massada, 2009). The MTT algorithm in Randig is multi- threaded (computations for a given fire are performed on multiple processors), making it feasible to perform Monte Carlo simulations of many fires $(>50000)$ to generate burn probability surfaces for very large ( $>2$ million ha) landscapes (Ager and Finney, 2009). The MTT algorithm is now being applied daily for operational wildfire problems throughout the USA (http://www.fpa.nifc.gov, http://wfdss.usgs.gov/ wfdss/WFDSS_About.shtml). In contrast to Farsite (Finney, 1998), the MTT algorithm assumes constant weather and is used to model individual burn periods within a wildfire rather than a continuous spread of a wildfire over many days and weather scenarios. Relatively few burn periods account for the majority of the total area burned in large (e.g. $>5000$ ha) wildfires in the western USA, and wildfire suppression efforts have little influence on fire perimeters during these extreme events (Flowers et al., 1983; Podur and Martell, 2007).

For each treatment alternative, we simulated 30000 burn periods assuming random ignition locations within the study area. For simplicity, we equate discrete burn periods to a wildfire event, although an actual wildfire might consist of multiple burn periods over several days or weeks. The number of simulated burn periods was adequate to ensure that $>99 \%$ of $30 \times 30 \mathrm{~m}$ pixels with burnable fuels in the study area were burned at least once. For computational efficiency, fire growth calculations were performed with an output at $90 \mathrm{~m}$ resolution, generating $90 \times 90 \mathrm{~m}$ burn probability grids. Simulations were performed on a desktop computer equipped with 8 quad-core AMD Opteron ${ }^{\mathrm{TM}}$ processors ( $64 \mathrm{bit}, 2.41 \mathrm{GHz}$ ) with $64 \mathrm{~GB}$ RAM and required $6 \mathrm{~h}$ of processing per scenario. Wildfire simulation parameters were chosen to reflect the likelihood of future scenarios for escaped wildfires within the study area based on historical fire data of the surrounding National Forest lands, personal communication with local fire specialists, and the results from initial wildfire simulations. We derived the fuel moistures for the 97th percentile August weather scenario from local remote weather stations (Table 1). We simulated 8 -h wildfires with a $40 \mathrm{~km} \mathrm{~h}^{-1}$ wind. Wind was randomly simulated from three directions $(225,235$, and 245 degrees azimuth) for each burn period. The azimuths were chosen to represent the dominant wind patterns associated with historical lightning storms and a high frequency of ignitions on the forest. The fire size frequency distribution of simulated burn periods was compared to historical extreme events in southern and eastern Oregon, and reviewed by fire specialists.

Outputs from the wildfire simulations included the burn probability (BP) for each pixel:

$\mathrm{BP}=F / n$

where $F$ is the number of times a pixel burns and $n$ is the number of fires simulated. The BP for a given pixel is an estimate of the likelihood that a pixel will burn given a random ignition within the study area and burn conditions 
similar to the historic fires as described above. Randig outputs a vector of marginal burn probabilities BPi for each pixel which represents the probability of a fire at the $i$-th $0.5 \mathrm{~m}$ flame length category. Different flame lengths are predicted by the MTT fire spread algorithm depending on the direction the fire encounters a pixel relative to the major direction of spread (i.e. heading, flanking, or backing fire, Finney, 2002).

\subsection{Carbon pool modelling}

Carbon pools were quantified with the carbon outputs from the FVS-FFE (Hoover and Rebain, 2008; Reinhardt and Crookston, 2003; Reinhardt and Holsinger, 2010). FVSFFE estimates carbon using biomass conversion equations of Smith and Heath (2002) and Penman et al. (2003). Litter and duff pools are converted to carbon by using a multiplier of 0.37 , while the remaining living and dead biomass is converted using a multiplier of 0.5. FVS-FFE reports carbon stocks for aboveground live and dead, partitioned into branches, stems, and foliage. Belowground carbon is reported for live and dead roots. Carbon is also reported for down dead wood, forest floor litter and duff, as well as herbs and shrubs. Carbon stored in merchantable material removed via treatments is proportioned into wood products, landfill disposal, energy use and emissions (Rebain, 2009).

Carbon loss functions were built for each tree list by using FVS-FFE to simulate fires in each stand with predefined flame lengths ranging from $0.5 \mathrm{~m}$ to $10 \mathrm{~m}$ in $0.5 \mathrm{~m}$ increments (SIMFIRE and FLAMEADJ keywords). The post-fire carbon pools were then examined to determine the change in carbon at each flame length. Simulations were completed for both treated and untreated stands, and the loss functions were built from outputs representing post treatment in the year 2004. For treated stands, carbon losses resulted from the underburns, removal of non-merchantable material, and losses associated with the end-use merchantable material removed. Non-merchantable material was considered an emission at the time of treatment.

The current configurations of FVS and Randig do not allow for the exact matching of fire behaviours. Randig reports total flame length of the surface and, if initiated, crown fire. In contrast, the FVS FLAMEADJ keyword does not allow for the specifying of a total flame length (surface and crown); rather, it allows for the specification of a flame length for surface fires only. Moreover, FVS FLAMEADJ will not simulate crown fire initiation if it is parameterized with only a fire flame length (except as reported in the potential fire report). To simulate crown fires in the loss functions, we calculated a critical flame length (representing the threshold flame length between a surface fire and a crown fire) and imposed $100 \%$ crown consumption (via parameter 3 of the FLAMEADJ keyword) when the surface fire flame length exceeded the critical flame length.

\subsection{Expected carbon calculations}

The amount of post-wildfire carbon for all stands in the untreated and treated landscapes was matched with the surface burn probability data to calculate expected carbon for each 90 by $90 \mathrm{~m}$ pixel as follows:

$E[\mathrm{C}]_{j}=\left[\sum_{i=0}^{20}\left[\mathrm{BP}_{i j} \cdot \mathrm{SC}_{i j}\right]\right]+\mathrm{WPC}_{j}$

where

$E[C]_{j}=$ Expected carbon (mass per unit area) post-wildfire for pixel $j$,

$\mathrm{BP}_{i j}=$ conditional burn probability of wildfire intensity class $i$ reaching the pixel $j$,

$\mathrm{SC}_{i j}=$ total in-stand carbon, post-wildfire (and posttreatment, if treated) of wildfire intensity class $i$ burning in pixel $j$, and

$\mathrm{WPC}_{j}=$ carbon stored in wood products harvested from pixel $j$.

For the untreated scenario, $\mathrm{WPC}_{j}=0$ for all $j$. We let wildfire intensity class $i=0$ represent a 0 flame length (no wildfire) and, thus, $\mathrm{SC}_{0 j}$ represents total stand carbon posttreatment, without a wildfire.

The expected carbon change between the scenarios was calculated as the difference between the various carbon pools for each 90 by $90 \mathrm{~m}$ pixel.

The landscapes total expected change in carbon, $E[(\Delta \mathrm{C})]$, is calculated as follows:

$E[(\Delta \mathrm{C})]=\sum_{j=1}^{n}\left(E[\mathrm{C}]_{\mathrm{TRT}_{j}}-E[\mathrm{C}]_{\mathrm{NO}-\mathrm{TRT}_{j}}\right)$

where

$n=$ is the total number of pixels in the landscape,

$E[C]_{\mathrm{TRT}_{j}}=$ is the expected carbon post-treatment and postwildfire in pixel $j$; treated scenario,

$E[\mathrm{C}]_{\mathrm{NO}-\mathrm{TRT}_{j}}=$ is the expected carbon post-wildfire in pixel $j$; untreated scenario, and

$E[\mathrm{C}]_{\mathrm{TRT}_{J}}-E[\mathrm{C}]_{\mathrm{NO}-\mathrm{TRT}_{j}}=$ the carbon difference occurring in pixel $j$ as a result of treatment.

\section{Results}

Estimated total stand carbon for the study area averaged about 60 tonnes ha ${ }^{-1}$, compared to the 58 tonnes ha $^{-1}$ reported for the ponderosa pine (MT2) type studied by Reinhardt and Holsinger (2010), and 200-300 tonnes ha ${ }^{-1}$ reported by Hurteau and North (2009) for mixed conifer stands in the Sierra Nevada mountains. Thinning removals and underburning resulted in an average reduction of about 25 tonnes ha $^{-1}$, compared to about 24 tonnes ha $^{-1}$ in Reinhardt and Holsinger (2010). 
Table 2. Mean burn probabilities for the treated and untreated scenarios for the forested portion of the study area. Burn probability is the chance that a pixel burns given a random ignition in the study area and a resulting wildfire under the conditions described in the methods.

\begin{tabular}{llll}
\hline & $\begin{array}{l}\text { Treated } \\
\text { scenario }\end{array}$ & $\begin{array}{l}\text { Untreated } \\
\text { scenario }\end{array}$ & $\begin{array}{l}\text { Difference } \\
\text { (treated }- \\
\text { untreated) }\end{array}$ \\
\hline Within treatment units & 0.0123 & 0.0260 & -0.0136 \\
Outside treatment units & 0.0170 & 0.0210 & -0.0039 \\
All forested areas & 0.0166 & 0.0215 & -0.0048 \\
\hline
\end{tabular}

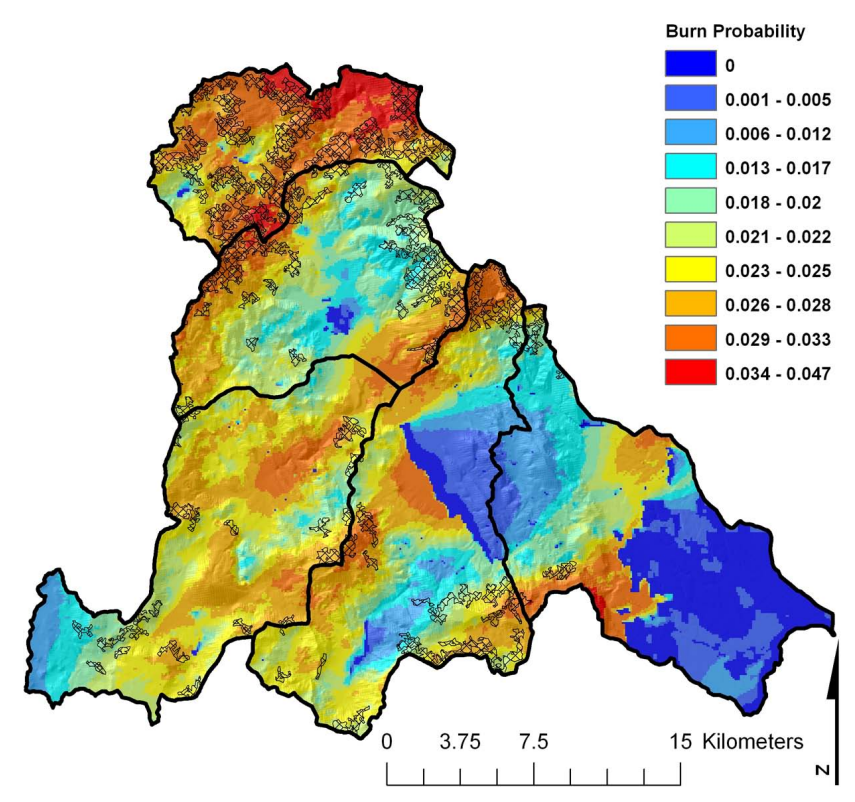

Fig. 2. Burn probability map generated from simulating 30000 wildfires with randomly located ignitions. Burn probability is the chance a pixel burns given a random ignition and resulting wildfire under the conditions used in the simulation.

Burn probability for the untreated landscape averaged 0.021 for the forested portion of the study area, and showed a reduction of about $22 \%$, to 0.016 , when the fuel treatments were simulated (Table 2, Figs. 2, 3). Burn probability within treated stands was reduced to about $54 \%$ between the nontreatment and treatment scenario. Burn probability in the treatment scenario was reduced for treated stands as well as stands outside the treatment area (Fig. 3). The size of the simulated fires for the study area, as a whole, was reduced from 3500 to 2370 ha by the fuel treatments, or about $32 \%$ (Fig. 4). The average wildfire size was reduced due to post-treatment changes in the simulated fuel models and associated spread rates. A reduction was also observed for the largest fire size, from 6070 ha for the treatment scenario, to 7689 ha for the non-treatment scenario.

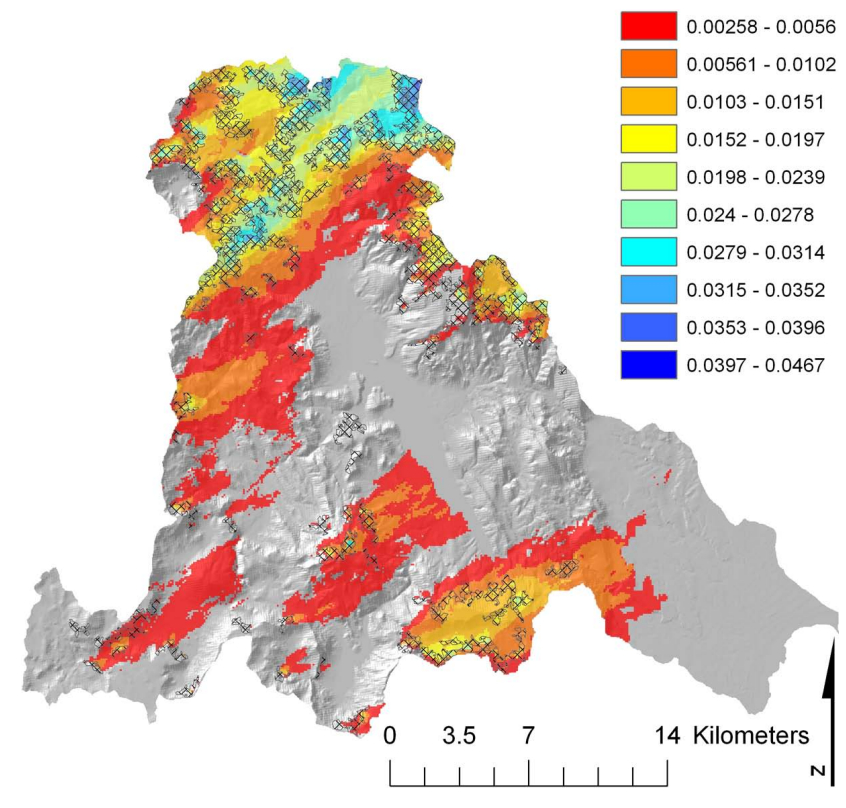

Fig. 3. Difference in burn probability between the non-treatment and treatment scenario. Areas not shaded within the watershed boundary had differences less than 0.00258 .

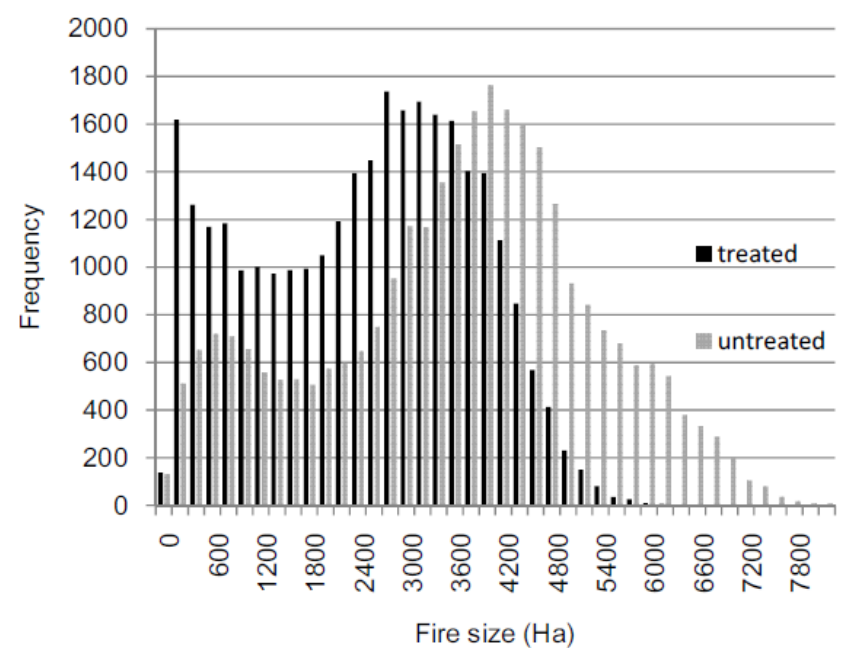

Fig. 4. Frequency histogram of fire size (ha) for the 30000 simulated wildfires for the non-treatment and treatment scenarios.

The simulated thinning treatment resulted in the removal of $19.1 \%$ of the total live tree biomass in the treated stands. About $61 \%$ of this removed live tree biomass was merchantable material as defined by FVS. The underburn following the thinning resulted in a loss of $13.3 \%$ of the total biomass.

The effect of fuel treatments and wildfire on carbon stocks for the forested portion of the study area is summarized in Table 3. The reported values are for expected carbon (except for carbon fixed in wood products), meaning the 
Table 3. Expected carbon (tonnes) for the non-treatment and treatment scenarios. Outputs are reported for the simulation year 2004 immediately after fuel treatments. Expected carbon is the estimated amount remaining after a random ignition and wildfire event in the study area, as estimated by simulating 30000 wildfire events. Total stand carbon includes live and dead trees, live and dead understory, standing and downed dead wood, litter and duff. Carbon stored is harvested carbon that is fixed in manufacturing products (e.g. lumber). Soil carbon is not modelled by FVS-FFE and is, therefore, not included in the calculations.

\begin{tabular}{lccc}
\hline Carbon pool & Untreated scenario & Treated scenario & $\begin{array}{c}\text { Difference } \\
\text { (untreated }- \text { treated) } \\
\text { (tonnes) }\end{array}$ \\
\hline Outside treatment units & (tonnes) & (tonnes) & -3208 \\
$\begin{array}{l}\text { Inside treatment units (and treated } \\
\text { in the treatment scenario) }\end{array}$ & 7683405 & 2686613 & 325760 \\
Carbon fixed in wood products & 0 & 438451 & \\
Total expected carbon & 3447616 & 3175532 & 272084 \\
\hline
\end{tabular}

average carbon on the treated and non-treated landscape after one random ignition and resulting severe wildfire event. Expected carbon for stands outside the treatment units was slightly larger for the treatment scenario (3208 tonnes) compared to the untreated scenario. In contrast, the expected carbon in the treated stands was dramatically reduced, from 764211 tonnes in the untreated scenario, to 438451 tonnes in the treated scenario, or a reduction of 325760 tonnes (Table 3). Thus, a net loss of expected carbon was observed for the treatment scenario despite lower burn probabilities and reduced wildfire severity.

Spatial patterns of the change in expected carbon from the treatments (Fig. 5) shows a relatively large loss of expected carbon $\left(>25\right.$ tonnes ha $^{-1}$ ) within the treatment units. A positive expected carbon was observed for many areas outside of the treatment areas, especially in locations where treatments impeded the spread of fires. A reduced burn probability and fire intensity both contributed to the carbon benefits outside the treatment units. However, the latter carbon benefits were generally in the order of 0.2 to 1.0 tonnes ha ${ }^{-1}$, compared to $>25$ tonnes ha $^{-1}$ for carbon losses within treatments. The fine scale pattern of carbon benefits outside the treatments (Fig. 6) reveals the same result of widespread, but relatively low expected carbon benefits outside the treatments, and large expected carbon losses within.

The approximate area of influence of the treatment as inferred by a reduction in burn probability on the lee side of the treatment area was delineated, and the mean expected carbon benefit in the treatment shadow was calculated at about 0.07 tonnes ha ${ }^{-1}$, or 538 tonnes carbon in total. This corresponds to a mean reduction in the overall conditional burn probability within the treatment shadow by -0.25 . From these calculations it is apparent that the carbon loss resulting from treatment significantly outweighs the carbon benefit in the treatment shadow area.

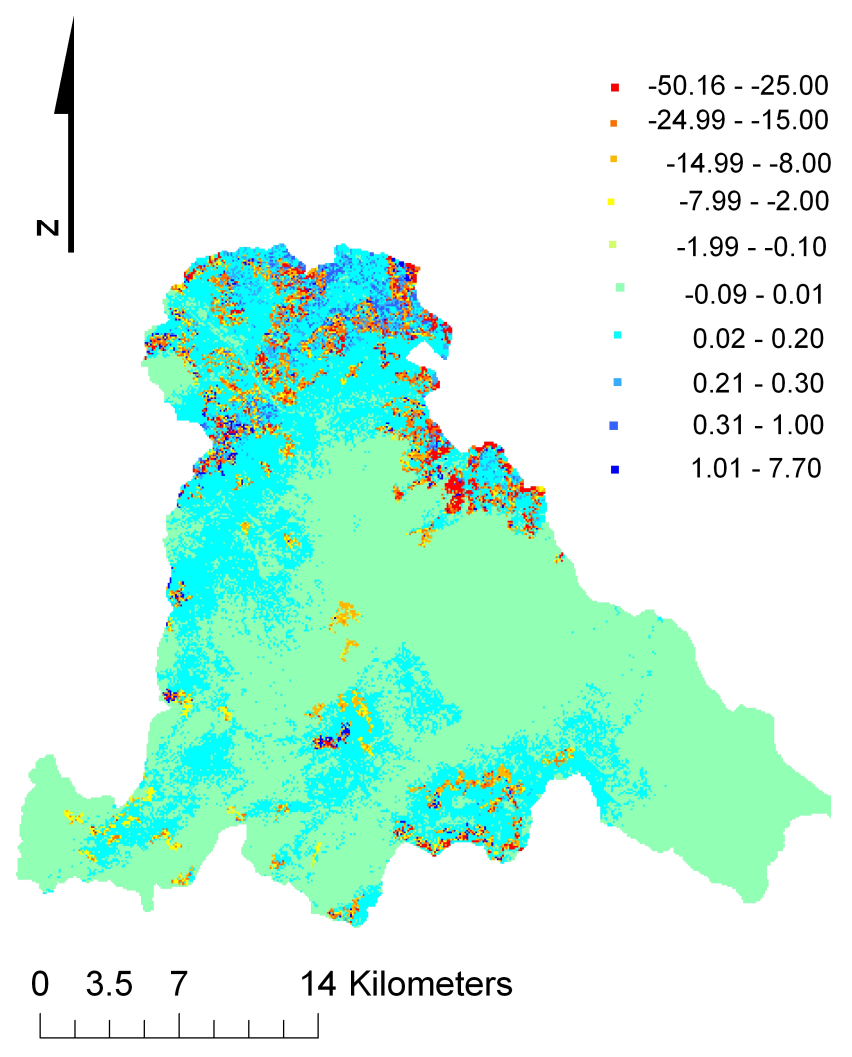

Fig. 5. Expected carbon difference (tonnes $\mathrm{ha}^{-1}$ ) between the nontreatment and treatment scenarios for the study area.

The fate of lost carbon for the forested land in the study area shows the bulk of the loss was from emissions associated with the underburn $(39.9 \%)$ and non-merchantable biomass removed from the site $(22.4 \%)$. Non-merchantable material generated from the simulated fuels mastication generated $19.5 \%$ of the emissions, as either decay or from pile burning (Table 4). The expected emissions from a single 


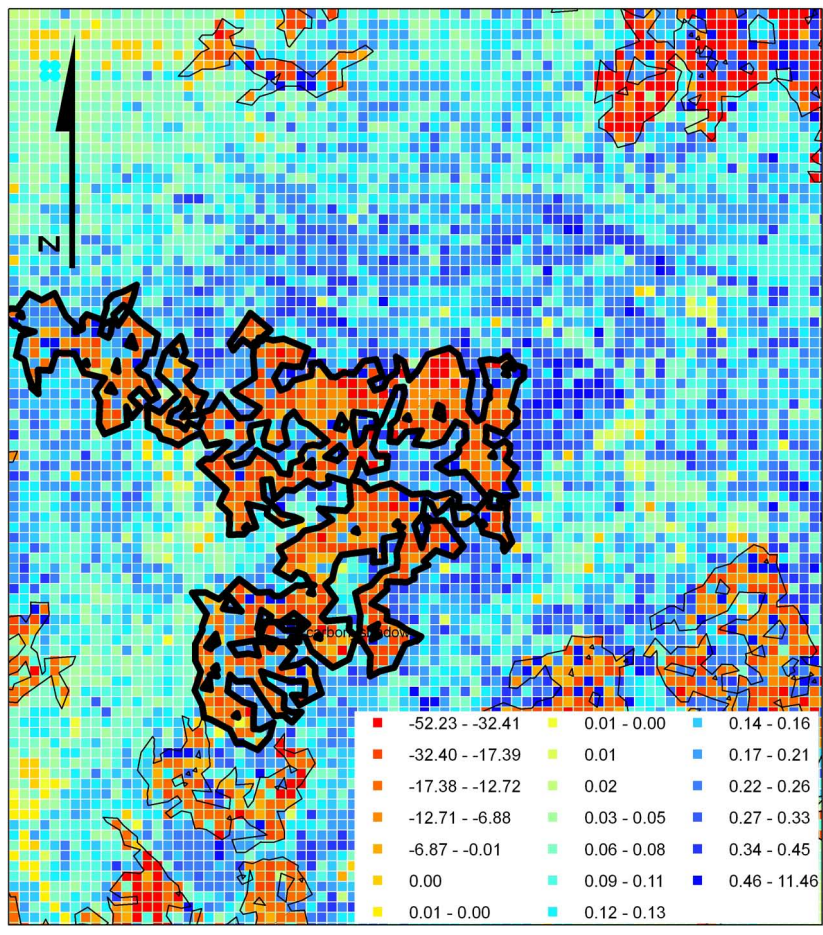

$\begin{array}{llll}0 & 1 & 2 & 4 \text { Kilometers }\end{array}$

Fig. 6. Zoomed image from Fig. 5 showing expected carbon differences (tonnes ha ${ }^{-1}$ ) between the non-treatment and treatment scenario. Treatment units are hatched polygons. Dominant fire spread direction is from the southwest to northeast. Image shows positive expected carbon on the outside of treated areas (blue pixels) where treatments impeded growth of simulated wildfires.

wildfire event for the treatment scenario was 8249 tonnes, with nearly all emissions generated outside the treatment units (8107 tonnes). Expected wildfire emissions for the non-treatment scenario totaled 14406 tonnes (3499 tonnes within treatment units, 10907 tonnes outside units) or an increase of about 6157 tonnes $(75 \%)$. The total expected carbon lost in all of the FVS pools (Table 3) amounted to 272084 tonnes, while the total expected emissions (Table 4) was 239993 tonnes, or 32091 tonnes less. The lower value for emissions resulted from higher decay rates of dead fuels within treatment units. Emissions associated with the decay of dead materials are not directly reported by FVS-FFE, even though the decayed biomass is subtracted from their respective pools. Both the thinning and the underburn treatments effectively transfer significant amounts of surface fuels into carbon pool classes which have faster decay rates.

\section{Discussion}

The study presented a risk framework to assess the effects of fuels management programmes on carbon that considers spatially explicit burn probabilities and landscape effects of management activities. We employed complex simulation methods with many sources of error and uncertainty, and the study area represents a narrow dimension of forests, fuels and fire regimes in the western USA. A number of factors could significantly change the results presented here, especially those related to treatment parameters and their effect on wildfire behaviour (spread rate and intensity) and resulting carbon emissions. While there is strong empirical data showing that fuel treatments reduce spread rates and intensity (Finney et al., 2005; Collins et al., 2007, 2009; Ritchie et al., 2007; Safford et al., 2009), there are instances where landscape treatment area and intensity were insufficient to significantly alter extreme fire events (Agee and Skinner, 2005). In the present study, treatment locations were not spatially optimized (Finney et al., 2007), and thus, their effect on reducing burn probability was not fully realised. Additional case studies are needed on large landscapes containing a range of forest types and fire regimes to better understand the topological relationships between fuel treatment strategies, fire risk, carbon and other ecological values as well (Ager et al., 2010). Both stand and landscape optimization methods are well developed and need to be explored in the current context (Bettinger et al., 2004). In particular, stand treatments need to be optimized to achieve maximum reduction in fire spread and intensity while minimizing emissions from underburns and decay of non-merchantable material.

Our study lacked a temporal element that is needed to account for: 1) the continued loss of carbon post wildfire from the decomposition of burned material; 2) continued sequestration that occurs both in treated stands and untreated stands; 3) lifecycle of fuel treatments, and 4) annual burn probability. The carbon loss functions developed with FVS showed that simulated wildfires effectively transfer the bulk of the carbon from the standing live to standing dead. Clearly, a temporal component is needed to capture the decomposition of the dead material over the life cycle of the fuel treatment to obtain a more robust estimate of fuel treatment effects on carbon emissions. Our simulations for a sample of stands (not reported here) suggested that the total carbon emissions from wildfire increased by $20-30 \%$ after 10 years. However, over the same period, forest regeneration on productive sites in the watershed could offset a significant portion of these emissions. The balance between carbon lost from the decomposition of the dead biomass versus the carbon sequestration from in-growth after treatments needs a more refined study on a range of ecological conditions. For instance, Reinhardt and Holsinger (2010) used FVS to simulate carbon stocks for seven forest types common in the western USA. Stands were simulated for 95 years with fuel treatments, wildfire and regeneration. In all forest types, fuel treatments did not result in a carbon benefit after the simulated wildfire. However, increased decay of the post-wildfire, standing dead in untreated stands relative to untreated led to about the same total stand carbon after about 
Table 4. Partitioning of carbon emissions (tonnes) on the forested portion of the study area for the treatment and non-treatment scenario.

\begin{tabular}{|c|c|c|c|}
\hline Emission source & $\begin{array}{c}\text { No treatment } \\
\text { scenario } \\
(\% \text { of total in column })\end{array}$ & $\begin{array}{c}\text { Treatment } \\
\text { scenario } \\
(\% \text { of total in column })\end{array}$ & $\begin{array}{l}\text { Difference (non-treatment } \\
\text { minus treatment scenario) } \\
\text { (\% of total difference) }\end{array}$ \\
\hline $\begin{array}{l}\text { Merchantable material removed from } \\
\text { site by treatment and assumed to } \\
\text { be emissions as part of manufacturing. }\end{array}$ & 0 & $37997(14.9 \%)$ & $-37997(15.8 \%)$ \\
\hline $\begin{array}{l}\text { Non-merchantable material removed from } \\
\text { site by treatment and assumed to be emissions } \\
\text { as part of manufacturing. }\end{array}$ & 0 & $56968(22.4 \%)$ & $-56968(23.7 \%)$ \\
\hline $\begin{array}{l}\text { Non-merchantable material removed via fuel- } \\
\text { move treatment, assumed to be slash disposal } \\
\text { via burning or decay after onsite chipping. }\end{array}$ & 0 & $49677(19.5 \%)$ & $-49677(20.7 \%)$ \\
\hline $\begin{array}{l}\text { Emissions from underburn treatment } \\
\text { in treated stands. }\end{array}$ & 0 & $101508(39.9 \%)$ & $-101508(42.3 \%)$ \\
\hline $\begin{array}{l}\text { Expected emission from a single random ignition } \\
\text { and resulting fire in the stands selected for } \\
\text { treatments (and treated in the treatment scenario). }\end{array}$ & $3499(24.3 \%)$ & $142(0.1 \%)$ & $-3357(-1.4 \%)$ \\
\hline $\begin{array}{l}\text { Expected emission from a single random ignition } \\
\text { and resulting fire in the stands outside the treatment } \\
\text { area (and not treated in the treatment scenario). }\end{array}$ & $10907(75.7 \%)$ & $8107(3.2 \%)$ & $-2800(-1.2 \%)$ \\
\hline Total emission & 14406 & 254399 & -239993 \\
\hline
\end{tabular}

40-50 years. It is difficult to interpret the temporal patterns in Reinhardt and Holsinger (2010) in relation to the present study since the effects of wildfires were deterministic rather than stochastic.

The BP modelling used here provided a relative measure of wildfire likelihood, i.e., the probability of a pixel burning given a single random ignition in the study area and a large fire event. The BP modelling made it possible to quantify effects of simulated management on carbon inside and outside of the treatment units. These off-site fuel treatment effects are rarely quantified in fuel treatment studies (Finney et al., 2005), although their importance is often discussed, especially in the context of protecting structures in the wildland urban interface areas (Reinhardt et al., 2008; Safford et al., 2009; Schoennagel et al., 2009).

Although the methods are an improvement over previous studies where wildfire occurrence was assumed, further work is needed to estimate annual burn probabilities as inputs for temporal analyses. There is insufficient fire history in the study area to estimate the temporal frequency of large fire events, but it is safe to conclude that it is significantly less than one per year. Fire suppression activities have been very effective in the study area, and the true BP is, therefore, less than the conditional estimates, making the fuel treatment even less attractive from a carbon standpoint. Newer models that use the MTT algorithm include spatiotemporal probabilities for ignition, escape and burn conditions, and yield estimates of annual BP (Finney, unpublished). Studies are also underway to better understand the topology and control of BP on large forested landscapes (e.g. Parisien et al., 2010; Ager and Finney, 2009).

While the fuel treatments within the study area reduced wildfire intensity and likelihood, the expected carbon change from fuel treatments was markedly negative. Of the 246150 tonnes of carbon removed through fuel treatments, only 50968 remained stored in wood products. Almost half (101508 tonnes) was directly emitted to the atmosphere from prescribed fire. In contrast, the expected, avoided wildfire emission from treatments was estimated at 6157 tonnes. The difference in these values is primarily caused by the deterministic nature of the treatments (probability $=1.0$ ) and the relative rare occurrence of a fire at a given pixel (probability $=0.016$ ). The expected benefit of avoided wildfire emissions is, therefore, reduced dramatically by low BP values.

Several previous studies concerning carbon and fuel treatments and forest management also suggest a net loss of carbon (Depro et al., 2008), even when severe wildfire events are modelled (Mitchell et al., 2009; Reinhardt and Holsinger, 2010). However, avoided emissions from wildfire as a result of thinning may well be significant, especially in the frequent, low-severity fire regimes (Finkral and Evans, 2008; Hurteau et al., 2008; North et al., 2009). Factoring in the low probability of a wildfire may alter these latter conclusions. 
It has been proposed that a strategic approach (Finney, 2001; Finney et al., 2007) to optimize the reduction in wildfire spread per treatment area is needed to minimize adverse carbon impacts (Mitchell et al., 2009). However, a major emphasis of fuel treatment programmes on federal lands is restoration of natural fire regimes on dry forests (USDA-USDI, 2001; HFRA, 2003; Sexton, 2006). On these sites, the current practice is to aggregate treatments to create landscapes where wildfires can be allowed to burn without adverse impacts of highly valued resources (e.g. wildlife habitat, old growth). As pointed out in Reinhardt et al. (2008), optimized fuel treatment patterns do not mimic natural fire processes, which is the long-term goal of forest restoration strategies on the extensive dry forests of the western USA.

Finally, it is important to note that fuel treatment projects have multiple objectives all directed toward creating forest landscapes that are more resilient to a battery of common disturbance agents (wildfire, bark beetles, defoliators and pathogens) and protect human values in communities at risk (Ager et al., 2010). Thus, quantifying the net change in wildfire risk from fuel treatment programmes requires summing (Eq. 1) across all pertinent values of interest, including carbon.

Acknowledgements. We thank Brian Watt on the Fremont-Winema National Forest for his assistance with fuel treatment prescriptions and fuels data. We also thank Bridget Naylor for expert help with the preparation of figures.

Edited by: R. Lasaponara

Reviewed by: P. Fiorucci and another anonymous referee

\section{References}

Agee, J. K. and Skinner, C. N.: Basic principles of fires fuel reduction treatments, Forest Ecol. Manag., 211, 83-96, 2005.

Agee, J. K., Bahro, B. B., Finney, M. A., Omi, P. N., Sapsis, D. B., Skinner, C. N., van Wagtendonk, J. W., and Weatherspoon, C. P.: The use of shaded fuelbreaks in landscape fire management, Forest Ecol. Manag., 127, 55-66, 2000.

Ager, A. A. and Finney, M. A.: Application of wildfire simulation models for risk analysis, Geophysical Research Abstracts, EGU General Assembly, Vol. 11, EGU2009-5489, 2009.

Ager, A. A., Finney, M. A., and Bahro, B.: Automating fireshed assessments and analyzing wildfire risk with ArcFuels, Forest Ecol. Manag., 234S, p. 215, 2006.

Ager, A. A., Finney, M. A., Kerns, B. K., and Maffei, H.: Modeling wildfire risk to northern spotted owl (Strix occidentalis cuariana) habitat in Central Oregon, USA, Forest Ecol. Manag., 246, 4556, 2007.

Ager, A. A., Vaillant, N., and Finney, M. A.: A comparison of landscape fuel treatment strategies to mitigate wildland fire risk in the urban interface and preserve old forest structure, Forest Ecol. Manag., 259, 1556-1570, 2010.
Anderson, D. H., Catchpole, E. A., DeMestre, N. J., and Parkes, T.: Modelling the spread of grass fires, J. Austral. Math. Soc. B., 23, 451-466, 1982.

Arca, B., Duce, P., Laconi, M., Pellizzaro, G., Salis, M., and Spano, D.: Evaluation of FARSITE simulator in Mediterranean maquis, Int. J. Wildland Fire, 16, 563-572, 2007.

Bachelet, D., Neilson, R. P., Lenihan, J. M., and Drapek, R. J.: Climate change effects on vegetation distribution and carbon budget in the United States, Ecoystems, 4, 164-185, 2001.

Bettinger, P., Graetz, D., Ager, A. A., and Sessions, J.: The SafeD forest landscape planning model, in: Methods for integrating modelling of landscape change: Interior Northwest Landscape Analysis System, technically edited by: Hayes, J. L., Ager, A. A., and Barbour, R. J., U.S. Department of Agriculture, Forest Service, Pacific Northwest Research Station, Portland, OR, Gen. Tech. Rep. PNW-GTR-610, Chapter 4, 41-63, 2004.

Calkin, D. E., Ager, A. A. Gilbertson-Day, J., Patten, C., Scott, J., and Quigley, T.: A wildfire risk assessment for the continental United States, Rocky Mountain Research Station, General Technical Report, RMRS-GTR-235, 62 pp., 2010.

Carmel, Y., Shlomit P., Faris, J., and Shoshany, M.: Assessing fire risk using Monte Carlo simulations of fire spread, Forest Ecol. Manag., 257, 370-377, 2009.

Collins, B. M., Kelly, M., van Wagtendonk, J. W., and Stephens, S. L.: Spatial patterns of large natural fires in Sierra Nevada wilderness areas, Landscape Ecol., 22, 545-557, 2007.

Collins, B. M., Miller, J. D., Thode, A. E., Kelly, M., van Wagtendonk, J. W., and Stephens, S. L.: Interactions among wildland fires in a long-established Sierra Nevada natural fire area, Ecosystems, 12, 114-128, 2009.

Depro, B. M., Murray, B., Alig, R., and Shanks, A.: Public Land, Timber Harvests, and Climate Mitigation: Quantifying Carbon Sequestration Potential on U.S. Public Timberlands, Forest Ecol. Manag., 255, 1122-1134, 2008.

Dixon, G. E.: Essential FVS: A user's guide to the Forest Vegetation Simulator, USDA Forest Service, Fort Collins, CO, USA, Forest Management Service Center Internal Report, 193 pp., 2003.

Finkral, A. and Evans, A.: The effects of a thinning treatment on carbon stocks in a northern Arizona ponderosa pine forest, Forest Ecol. Manag., 255, 2743-2750, 2008.

Finney, M. A.: Modeling the spread and behavior of prescribed natural fires, Proc. 12th Conf. Fire and Forest Meteorology, Jekyll Island, GA, USA, 138-14, 1994.

Finney, M. A.: FARSITE: Fire Area simulator - model development and evaluation, USDA Forest Service, Rocky Mountain Research Station, Technical Report RP-4, 1998.

Finney, M. A.: Design of regular landscape fuel treatment patterns for modifying fire growth and behaviour, Forest Sci., 47, 219228, 2001.

Finney, M. A.: Fire growth using minimum travel time methods, Can. J. Forest Res., 32, 1420-1424, 2002.

Finney, M. A.: The challenge of quantitative risk analysis for wildland fire, Forest Ecol. Manag., 211, 97-108, 2005.

Finney, M. A.: An overview of FlamMap fire modeling capabilities, in: Fuels Management-How to Measure Success: Conference Proceedings, 28-30 March 2006, Portland, OR, edited by: Andrews, P. L. Butler, B.W., USDA Forest Service, Fort Collins, CO, Rocky Mountain Research Station Proceedings RMRS-P41, 213-220, 2006. 
Finney, M. A. and Cohen, J. D.: Expectation and evaluation of fuel management objectives, in: Fire, Fuel Treatments, and Ecological Restoration: Conference Proceedings, 16-18 April 2002, Fort Collins, CO, USDA Forest Service, Rocky Mountain Research Station Proceedings RMRS-P-29, 353-366, 2003.

Finney, M. A., McHugh, C. W., and Grenfell, I. C.: Stand- and landscape-level effects of prescribed burning on two Arizona wildfires, Can. J. Forest Res., 35, 1714-1722, 2005.

Finney, M. A., Seli, R. C., McHugh, C. W., Ager, A. A., Bahro, B., and Agee, J. K.i Simulation of long-term landscape-level fuel treatment effects on large wildfires, Int. J. Wildland Fire, 16, 712-727, 2007.

Flowers, P. J., Hunter, T. P., and Mills, T. J.: Design of a model to simulate large-fire suppression effectiveness, in: Proceedings of the 7th Conference on Fire and Forest Meteorology, Boston, Massachusetts, American Meteorological Society, 168-173, 1983.

Gedalof, Z., Peterson, D. L., and Mantua, N. J.: Atmospheric, climatic, and ecological controls on extreme wildfire years in the northwestern United States, Ecol. Appl., 15, 154-174, 2005.

Healthy Forest Restoration Act: Healthy Forest Restoration Act [HFRA] of 2003, Public Law 108-148, Statutes at Large 117, 2003.

Hoover, C. and Rebain, S.: The Kane Experimental Forest carbon inventory: carbon reporting with FVS, Pp. 17-22, in: Third Forest Vegetation Simulator Conference, 13-15 February 2007, Fort Collins, CO, edited by: Havis, R. N. and Crookston, N. L., USDA forest Service, Fort Collins, CO, Rocky Mountain Research Station, Proceedings RMRS-P-54, 234 pp., 2008.

Hurteau, M. and North, M.: Fuel treatment effects on tree-based forest carbon storage and emissions under modelled wildfire scenarios, Front. Ecol. Environ., 7, 409-414, 2009.

Hurteau, M. D., Kock, G. W., and Hungate, B. A.: Carbon protection and fire risk reduction: toward a full accounting of forest carbon offsets, Front. Ecol. Environ., 6, 493-498, doi:10.1890/0701876, 2008.

Knight, I. and Coleman, J.: A fire perimeter expansion algorithm based on Huygens' wavelet propagation, Int. J. Wildland Fire, 3(2), 73-84, 1993.

Krasnow, K. T., Schoennagel, T. T., and Veblen, T.: Forest fuel mapping and validation of LANDFIRE fuel maps in Boulder County, Colorado, Forest Ecol. Manag., 257, 1603-1612, 2009.

LaCroix, J. J., Ryu, S. R., Zheng, D., and Chen, J.: Simulating Fire Spread with Landscape Management Scenarios, Forest Sci., 52, 522-529, 2006.

Massada, A. B., Redeloff, V., Stewart, S., and Hawbaker, T. J.: A simulation study in northwestern Wisconsin, Forest Ecol. Manag., 258, 1990-1999, 2009.

McKenzie, D., Gedalof, Z., Peterson, D. L., and Mote, P.: Climatic change, wildfire, and conservation, Conserv. Biol., 18, 890-902, 2004.

Miller, J. D. and Yool, S. R.: Modeling fire in semi-desert grassland/oak woodland: the spatial implications, Ecol. Model., 153, 229-245, 2002.

Mitchell, S. R., Harmon, M. E., and O'Connell, K.B.: Forest fuel reduction reduces both fire severity and long-term carbon storage in three Pacific Northwest Ecosystems, Ecol. Appl., 19, 643-655, 2009.
North, M., Hurteau, M., and Innes, J.: Fire suppression and fuels treatment effects on mixed-conifer carbon stocks and emissions, Ecol. Appl., 19, 1385-96, 2009.

Ohmann, J. L. and Gregory, M. J.: Predictive mapping of forest composition and structure with direct gradient analysis and nearest-neighbor imputation in coastal Oregon, U.S.A., Can. J. Forest Res., 32, 725-741, 2002.

Parisien, M.-A., Miller, C., Ager, A. A., and Finney, M. A.: Use of artificial landscapes to isolate factors controlling spatial patterns in burn probability, Landscape Ecol., 25, 79-94, 2010.

Penman, J., Gytarsky, M., and Hiraishi, T.: Good practice guidance for land use, land use change, and forestry, Institute for Global Environmental Strategies for the Intergovernmental Panel on Climate Change Hayama, Kanagawa, Japan, 502 pp., 2003.

Podur, J. J. and Martell, D. L.: A simulation model of the growth and suppression of large forest fires in Ontario, Int. J. Wildland Fire, 16, 285-294, 2007.

Rebain, S. A.: The fire and fuels extension to the Forest Vegetation Simulator, Addendum to RMRS-GTR-119, USDA Forest Service and ESSA Technologies Ltd., 244 pp., 2009.

Reinhardt, E. D. and Crookston, N. L. (Tech. Eds): The fire and fuels extension to the forest vegetation simulator, USDA Forest Service, Ogden, UT, Rocky Mountain Research Station General Technical Report RMRS-GTR-116, 209 pp., 2003.

Reinhardt, E. and Holsinger, L.: Effects of fuel treatments on carbon-disturbance relationships in forests of the northern Rocky Mountains Forest Ecol. Manag., 259, 1427-1435, 2010.

Reinhardt, E. D., Keane, R. E., and Brown, J. K.: First Order Fire Effects Model: FOFEM 4.0 user's guide, US Department of Agriculture, Forest Service, Intermountain Research Station, Ogden, UT, Gen. Tech. Rep. INT-GTR-344, 65 pp., 1997.

Reinhardt, E. D., Keane, R. E., Calkin, D. E., and Cohen, J. D.: Objectives and considerations for wildland fuel treatment in forested ecosystems of the interior western United States, Forest Ecol. Manag., 256, 1997-2006, 2008.

Richards, G. D.: An elliptical growth model of forest fire fronts and its numerical solutions, Int. J. Numer. Meth. Eng., 30, 11631179, 1990.

Ritchie, M. W., Skinner, C. N., and Hamilton, T. A.: Probability of wildfire-induced tree mortality in an interior pine forests: effects of thinning and prescribed fire, Forest Ecol. Manag., 247, 200208, 2007.

Rollins, M. G.: LANDFIRE: a nationally consistent vegetation, wildland fire, and fuel assessment, Int. J. Wildland Fire, 18, 235249, 2009.

Safford, H. D., Schmidt, D. A., and Carlson, C. H.: Effects of fuel treatments on fire severity in an area of wildland-urban interface, Angora Fire, Lake Tahoe Basin, California, Forest Ecol. Manag., 258, 773-787, 2009.

Sanderlin, J. C. and Van Gelder, R. J.: A simulation of fire behaviour and suppression effectiveness for operation support in wildland fire management, in: Proc. 1st Int. Conv. on mathematical modelling, St. Louis, MO, 619-630, 1977.

Schoennagel, T., Nelson, C. R., Theobald, D. M., Carnwath, G. C., and Chapman, T. B.: Implementation of National Fire Plan treatments near the wildland-urban interface in the western United States, Proceedings National Academy of Sciences, early edn.: 8 June, 2009. 
Sexton, T.: U.S. federal fuel management programs: reducing risk to communities and increasing ecosystem resilience and sustainability, 9-12 pp., in: Fuels Management-How to Measure Success, compiled by: Andrews, P. L. and Butler, B. W., Conference Proceedings, Portland, OR, 28-30 March 2006 Fort Collins, CO: USDA Forest Service, Rocky Mountain Research Station Proceedings RMRS-P-41, 809 pp., 2006.

Scott, J. H. and Burgan, R. E.: Standard fire behavior fuel models: a comprehensive set for use with Rothermel's surface fire spread model. USDA Forest Service, Rocky Mountain Research Station, Fort Collins, CO, Gen. Tech. Rep. RMRS-GTR-153, 72 pp., 2005.

Smith, J. E. and Heath, L. S.: A model of forest floor carbon biomass for United States forest types, USDA, Forest Service, Northeastern Research Station, Newtown Square, PA, Res. Pap. NE-722, 37 pp., 2002.

Stephens, S. L. and Moghaddas, J. J.: Experimental fuel treatment impacts on forest structure, potential fire behaviour, and predicted tree mortality in a California mixed conifer forest, Forest Ecol. Manag., 215, 21-36, 2005.
Stephens, S. L., Moghaddas, J. J., Edminster, C., Fiedler, C. E., Haase, S., Harrington, M., Keeley, J. E., Knapp, E. E., McIver, J. D., Metlen, K., Skinner, C. N., and Youngblood, A.: Fire treatment effects on vegetation structure, fuels, and potential fire severity in western U.S. forests, Ecol. Appl., 19, 305-320, 2009.

USDA Forest Service: A strategic assessment of forest biomass and fuel reduction treatments in Western States, Fort Collins, CO: USDA Forest Service, Rocky Mountain Research Station, Gen. Tech. Rep. RMRS-GTR-149, 17 pp., 2005.

Vaillant, N. M., Fites-Kaufman, J., Reiner, A. L., Noonan-Wright, E. K., and Dailey, S. N.: Effect of fuel treatments on fuels and potential fire behaviour in California, USA, National Forests, Fire Ecology, 5, 14-29, 2009.

van Wagtendonk, J. W.: Use of a deterministic fire growth model to test fuel treatments, in: Pp 1155-66 in Sierra Nevada Ecosystems Project: Final Report to Congress, vol. II. Assessments and Scientific Basis for Management Options, University of California, Davis, Centers for Water and Wildland Resources, 1996. 